\title{
Rapid screening of high expressing Escherichia coli colonies using a novel dicistronic-autoinducible system
}

\author{
Fatemeh Sadat Shariati, Dariush Norouzian, Vahideh Valizadeh, Reza Ahangari Cohan ${ }^{*}$ (I) and Malihe Keramati
}

\begin{abstract}
Background: Identification of high-expressing colonies is one of the main concerns in the upstream process of recombinant protein development. The common method to screen high-producing colonies is SDS-PAGE, a laborious and time-consuming process, which is based on a random and qualitative way. The current study describes the design and development of a rapid screening system composed of a dicistronic expression system containing a reporter (enhanced green fluorescent protein, eGFP), protein model (staphylokinase, SAK), and a self-inducible system containing heat shock protein 27 (Hsp27).

Results: Dicistronic-autoinducible system expressed eGFP and SAK successfully in 5-ml and 1-L culture volumes. High expressing colonies were identified during $6 \mathrm{~h}$ via fluorescent signals. In addition, the biological activity of the protein model was confirmed semi-quantitatively and quantitatively through radial caseinolytic and chromogenic methods, respectively. There was a direct correlation between eGFP fluorescent intensity and SAK activity. The correlation and linearity of expression between the two genes were respectively confirmed with Pearson correlation and linear regression. Additionally, the precision, limit of detection (LOD), and limit of quantification (LOQ) were determined. The expression of eGFP and SAK was stable during four freeze-thaw cycles. In addition, the developed protocol showed that the transformants can be inoculated directly to the culture, saving time and reducing the error-prone step of colony picking.

Conclusion: The developed system is applicable for rapid screening of high-expressing colonies in most research laboratories. This system can be investigated for other recombinant proteins expressed in E. coli with a potential capability for automation and use at larger scales.
\end{abstract}

Keywords: Dicistronic expression system, Rapid screening, Escherichia coli, Self-inducible expression system, Enhanced green fluorescent protein

\section{Introduction}

Escherichia coli is a suitable host for the initial screening of recombinant protein expression owing to easy genetic manipulation, inexpensive culture, and rapid growth $[1$, 2]. However, conventional methods for identification of colonies with high production levels of target protein

*Correspondence: cohan_r@pasteur.ac.ir; keramati.malihe@gmail.com Department of Nanobiotechnology, New Technologies Research Group, Pasteur Institute of Iran, Tehran, Iran require several time-consuming steps, including (i) vector transformation, (ii) plating the transformed cells, (iii) colony picking, (iv) inoculating the colony to a preculture, (v) inoculating the final culture with the pre-culture, (vi) optical density monitoring, (vii) induction of expression, and finally, (viii) the investigation of protein expression through a detection method. In this regard, the most common detection method is the SDS-PAGE technique in which several limited clones are randomly analyzed qualitatively or semi-quantitatively to distinguish non- or original author(s) and the source, provide a link to the Creative Commons licence, and indicate if changes were made. The images or other third party material in this article are included in the article's Creative Commons licence, unless indicated otherwise in a credit line to the material. If material is not included in the article's Creative Commons licence and your intended use is not permitted by statutory regulation or exceeds the permitted use, you will need to obtain permission directly from the copyright holder. To view a copy of this licence, visit http://creativecommons.org/licenses/by/4.0/. The Creative Commons Public Domain Dedication waiver (http://creativeco mmons.org/publicdomain/zero/1.0/) applies to the data made available in this article, unless otherwise stated in a credit line to the data. 
low-expressing clones from high-expressing ones [2]. The screening with the SDS-PAGE technique is laborintensive, time-consuming, and usually restricted to a limited number of colons that may lead to missing high expressing colons. The emerging techniques, such as fluorescence-activated cell sorting (FACS) and robotic platforms, facilitate the colony selection program. These systems take the benefit of simultaneous cell sorting based on several parameters and automated systematic screening of multi-well plates [3]. Meanwhile, expensive equipment and special expertise might not be available in every research laboratory. In addition, in these platforms, even with automation, the protein production pipeline often consists of several steps that have to be linked together and require manual interventions. Moreover, these platforms require high-resolution imaging systems to monitor the colonies growing on the agar surface and discriminate them based on user-selectable criteria, such as diameter and roundness. Therefore, these platforms are not cost-effective and in the practice, the screening of expression is carried out semi-quantitatively [4].

Reporter proteins that can fuse to the $\mathrm{N}$ - or $\mathrm{C}$-terminus of target proteins have been suggested for the screening of expression [5, 6]. The development of enhanced green fluorescent protein (eGFP) and other fluorescence-based proteins has opened new opportunities for screening purposes. These protein reporters do not need an external substrate or cofactor, work in a wide range of conditions $(\mathrm{pH}$, temperature, salt concentration, detergents, and protease), are non-toxic, and are detectable quantitatively by fluorimetry [4]. However, removal of the reporter is usually necessary following expression since it may affect the structure and function of the target protein [7]. Development and use of dicistronic expression systems have resolved this obstacle $[8,9]$.

Dicistronic expression systems are classified into two categories. In the first category, dicistronic expression vectors consist of two gene insertion sites in which the expression of each gene was separately controlled under a unique promoter. These systems have a wide application in the coexpression of binary protein complexes or twoindependent proteins $[9,10]$. However, in these systems, the level of expression in the first position is not proportional to the second position and they therefore cannot be ideal for screening purposes. While in the second category, both genes are controlled under the same promoter but distinct in the ribosome-binding sites (RBS). In these systems, the expression of the second gene is comparable to the first gene and therefore, they are suitable for screening purposes by employing reporters [10-12].

The other strategy to facilitate colony screening is the use of self-inducible expression (SILEX) systems. SILEX systems are efficient producing systems for removing the toxicity effect of inducer on the host cells. These systems do not require optical density monitoring for induction and work at different temperatures $\left(20\right.$ to $\left.37^{\circ} \mathrm{C}\right)$ and in a variety of common culture media (LB, TB, and $2 \mathrm{YT}$ ). They are simpler and more cost-effective than other strategies, such as the use of Studier self-induction culture media or the use of promoters inducing a metabolic change. It is also possible to study the protein expression in 96 well microplates through these systems [13]. Miniaturization of such systems usually saves time and cost and decreases manual handling steps and errors [2, 14].

In the current study, we developed a simple screening system at a micro-scale that can be used for rapid screening of high-expressing colonies in E. coli. The designed system is a combination of a dicistronic expression cassette containing T7-promoter, the gene of interest (Staphylokinase, SAK), ribosome binding site, and an eGFP (enhanced green fluorescent protein) as a reporter gene. The pelB sequence was embedded in all constructs for secreting proteins into periplasm to simplify the screening procedure and improve the protein folding. The expression is auto-induced via a self-inducible expression system using heat shock protein 27 (Hsp27).

\section{Results \\ Design of screening protocol}

To screen quantitatively high-expressing colonies in a short time, a dicistronic expression system was designed. At this dicistronic system, SAK was selected as a suitable model protein at the first gene site since its activity can be measured quantitatively and qualitatively using chromogenic and caseinolytic assays, respectively. Moreover, an eGFP was utilized as a reporter protein at the second gene site. This system auto-induces the expression of a model protein (SAK) with the leaky expression of Hsp27 and omits the optical density monitoring and the need for an inducer (IPTG). Of course, the proposed protocol can also be investigated for other recombinant proteins.

To set up the protocol, the following several optimization steps were carried out. In the double transformation process, different amounts of plasmids were tested to get approximately 100 double-transformed clones by plating on the LB agar plates containing both selective antibiotics followed by colony counting. The result indicated that 200-300 ng of plasmids are needed to obtain the specified number of double-transformed clones (Additional file 1: Table S1). Moreover, for removing the spreading step of newly double transformed cells on LB agar plate, direct inoculation of transformation solution to each well of 96-microplate was proposed. For this reason, the inoculation was examined at different volumes of the newly transformed suspension on LB agar plates containing both selective antibiotics to obtain a single clone in each 
well of 96-microplate. The data revealed that $10 \mu \mathrm{l}$ is the smallest volume of the newly transformed bacterial suspension (according to facilitated screening protocol) to obtain a single clone (Additional file 2: Table S2). Elimination of colony culturing step on LB agar plate and the removal of preculture step reduces the time of screening process by up to 2 days compared to the SDS-PAGE technique.

The optimum time for fluorimetry was achieved at $6 \mathrm{~h}$ after the inoculation of transformants. As depicted in Additional file 3: Fig. S1, the slope of the graph is higher at $6 \mathrm{~h}$ than the other times. Therefore, eGFP expression level among different clones is determined quantitatively $6 \mathrm{~h}$ after inoculation via fluorescent signals while in the SDS-PAGE technique, the expression results of different clones are usually investigated qualitatively or semi-quantitatively at 6 to $18 \mathrm{~h}$ after inoculation. The fluorescence sensitivity of the fluorimeter was set to $60 \mathrm{RFU}$ (Relative Fluorescent Unit) to obtain a reliable response (Additional file 4: Fig. S2). The fluorescence signal measurements and SAK activity assay were performed to check the correlation between the model protein and eGFP expressions in the first and second insertion sites, respectively. In addition, the optimization of doubletransformation for obtaining $\sim 100$ clones and the step to obtain a double transformed clone in each well of 96-microplate was repeated three times in three different days (with a one-week interval) to check the precision, linearity, limit of detection (LOD), and limit of quantification (LOQ) (Table 1) [15]. The results revealed a suitable precision for all the steps in the proposed protocol. The linearity between the fluorescence signal and the SAK activity was confirmed through the linear regression method with a coefficient of determination $\left(R^{2}\right)$ of 0.9623 . Thus, by measuring fluorescent signals in different clones of the designed system, high-staphylokinase expressing clones were screened in a short time. The LOD and LOQ for fluorimetry signals were respectively calculated as 3155.52 (Mean + 3SD) and 3497.40 (Mean + 10SD) RFU. These values were corresponded to $0.68 \mathrm{IU} / \mathrm{mg}$ and $27.53 \mathrm{IU} / \mathrm{mg}$ of SAK activity, respectively. In conventional screening techniques, such as SDS-PAGE, the sensitivity of detection mainly depends on the gel staining method, for example $30 \mathrm{ng}$ for Colloidal Coomassie Brilliant Blue G-250, $100 \mathrm{ng}$ for Coomassie Brilliant Blue R-250, and 5-10 ng for silver staining. Although silver staining has a high sensitivity for detecting purified proteins at nanogram range, this method can only qualitatively detect the expression of target protein in the cell extract. While the proposed protocol can measure the smaller amount of target protein in the cell extract via fluorescent signals.

\section{Expression analysis of SAK with SDS-PAGE, western blot, and purification}

The expression of eGFP and SAK proteins through the Hsp27 SILEX system was analyzed applying 15\% SDSPAGE at 5-ml and 1-L cultures. The stained gels showed that eGFP and SAK proteins were expressed respectively at molecular weights of $\sim 28$ and $15.5 \mathrm{kDa}$, (Fig. 1a). Moreover, the SAK expression was also confirmed after affinity purification (Fig. 1b) and western blot (Fig. 1c).

\section{Enzyme activity measurements}

Radial caseinolytic and chromogenic methods were employed to confirm the activity of SAK after expression in dicistronic SILEX system. A clear zone was detected around the wells on account of the proteolytic activity of the enzyme in caseinolytic assay (Additional file 5: Fig. S3). The SAK activity measured with radial caseinolytic assay for three different clones is summarized in Table 2 . The activity of expressed SAK in the selected clones was also confirmed through the chromogenic method (Table 3). The results shed light on the linear relationship between the SAK activity (IU/mg) and the absorbance at a wavelength of $405 \mathrm{~nm}$ (Additional file 6: Fig. S4).

\section{Correlation between fluorescence signals and SAK chromogenic activity}

To investigate the correlation between fluorescence signals and SAK chromogenic activity, 50 clones were first screened by fluorimetry $6 \mathrm{~h}$ after inoculation (Additional file 7: Table S3). The lowest and highest fluorescent signals respectively were $13,459 \pm 556.5$ and $36,306 \pm 872.55$ RFU. Ten clones with maximum

Table 1 Calculation of validation parameters for the screening protocol

\begin{tabular}{|c|c|c|c|c|c|}
\hline Step & Average & SD & RSD (\%) & LOD & LOQ \\
\hline Fluorescence signal measurement (RFU) & $34,791.44$ & \pm 753.31 & 2.16 & 3155.52 & 3497.40 \\
\hline SAK activity assay (IU/mg) & 184.87 & \pm 3.18 & 1.72 & 0.68 & 27.53 \\
\hline Number of double transformed clones & 107.33 & \pm 2.5 & 2.32 & - & - \\
\hline Obtaining a clone in each well of 96-microplate & 1 & \pm 0.00 & 0 & - & - \\
\hline
\end{tabular}

SD: standard deviation; RSD: relative standard deviation; LOD: limit of detection; LOQ: limit of quantification 


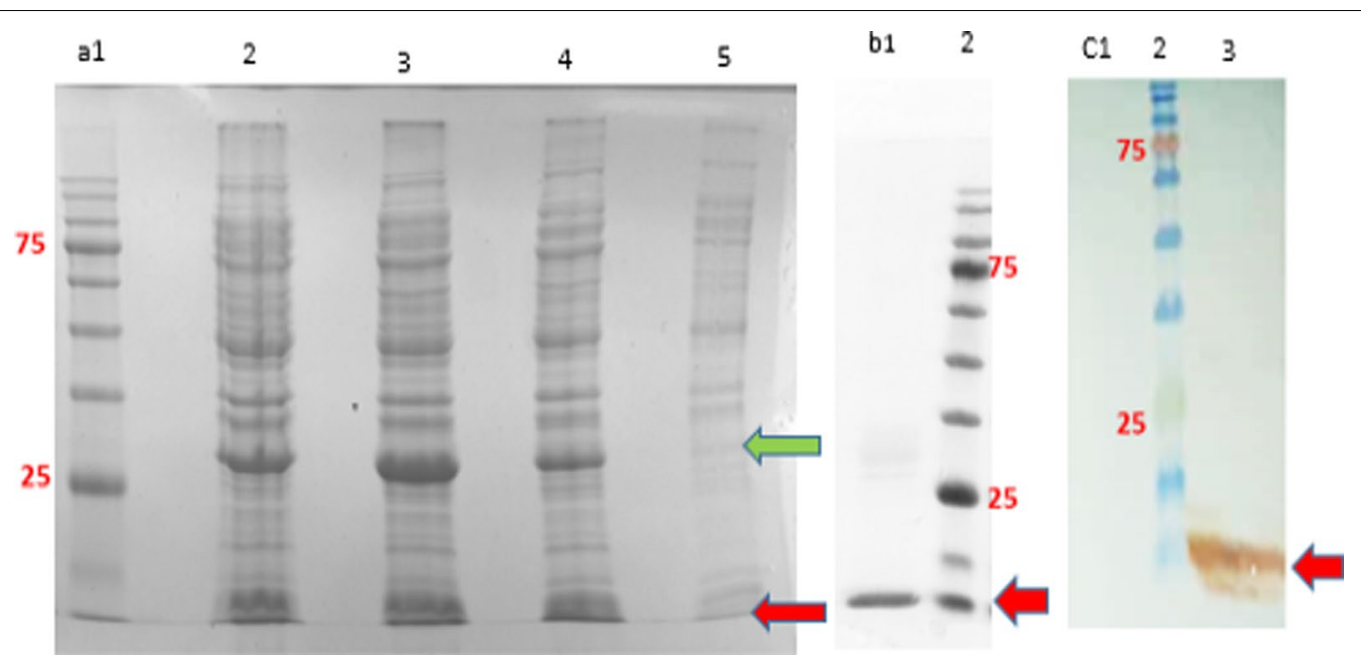

Fig. 1 The expression analysis of eGFP and SAK proteins in dicistronic SILEX system. a 15\% SDS-PAGE analysis of eGFP and SAK expression [Lane 1: protein marker, Lanes 2 and 3: $16 \mathrm{~h}$ after inoculation in 1-L culture at two different clones, lane 4: $16 \mathrm{~h}$ after inoculation in 5-ml culture, and Lane 5: $2 \mathrm{~h}$ after inoculation at 5-ml culture], b 15\% SDS-PAGE analysis of purified SAK [Lane1: purified SAK, Lane 2: protein marker], c western blot analysis of SAK protein [Lane 1: E. coli BL21 (DE3) containing pET28a-sak-rbs-egfp (negative control), Lane 2: protein marker, Lane 3: double transformed E. coli BL21 (DE3). The green and red arrows indicate eGFP and SAK proteins, respectively. The protein marker molecular weights are 180, 135, 100, 75, 63, $48,35,25,17$, and $11 \mathrm{kDa}$

Table 2 The result of radial caseinolytic assay of SAK

\begin{tabular}{llllll}
\hline Sample & Clone 1 & Clone 2 & Clone 3 & Positive Control $^{\mathbf{a}}$ & Negative Control $^{\mathbf{b}}$ \\
\hline Clear zone (cm) & $1.47 \pm 0.02$ & $1.44 \pm 0.03$ & $1.44 \pm 0.02$ & $1.53 \pm 0.03$ & $0.61 \pm 0.01$ \\
RSD (\%) & 1.31 & 2.30 & 1.50 & 2.43 & 2.67 \\
\hline
\end{tabular}

RSD: Relative standard deviation

${ }^{a}$ Recombinant SAK with plasminogen

${ }^{\mathrm{b}}$ Recombinant SAK without plasminogen. Data are represented as Mean \pm SD from three independent experiments

Table 3 The enzyme activity measurement using chromogenic method

\begin{tabular}{llllll}
\hline Sample & Clone 1 & Clone 2 & Clone 3 & Positive Control $^{\text {a }}$ & \begin{tabular}{l} 
Negative $_{\text {Control }^{\mathbf{b}}}$ \\
\hline SAK activity (IU/mg)
\end{tabular} \\
RSD (\%) & $188.32 \pm 2.18$ & $171.29 \pm 6.26$ & $143.59 \pm 5.11$ & $183.37 \pm 4.29$ & 0 \\
\hline
\end{tabular}

RSD: Relative standard deviation

${ }^{a}$ Recombinant SAK with plasminogen

${ }^{\mathrm{b}}$ Recombinant SAK without plasminogen. Data are represented as Mean \pm SD from three independent experiments

and minimum fluorescent signals were selected for the enzyme activity assay. The Pearson correlation was calculated between fluorescence signals and SAK activity. As shown in Fig. 2, as the fluorescent signal increases, the proteolytic activity of SAK also increases. There was a high positive correlation between the fluorescence signals and SAK activity (Pearson correlation coefficient $=0.9623$ ).

\section{The SAK expression and plasmid stability of dicistronic SILEX system}

The expression stability of dicistronic SILEX system was assayed by monitoring the SAK activity and the intensity of fluorescent signals within 80 days after four freezethaw cycles. The results demonstrated that the expression level for both proteins was maintained even after 80 days without a noticeable reduction (Fig. 3). In addition, the 


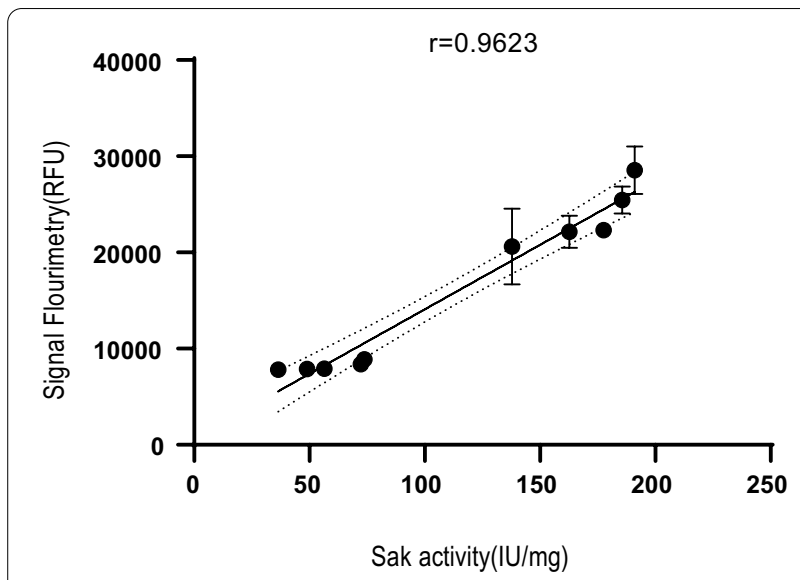

Fig. 2 Pearson correlation study between SAK chromogenic activity and fluorescence signals in dicistronic SILEX system. Data are represented with a 95\% confidence interval. Data are represented as Mean \pm SD from three independent experiments

colony PCR confirmed the plasmid stability of dicistronic SILEX system after 500 days of subculturing by amplifying $h s p 27$ and sak rbs egfp genes (Additional file 8: Fig. S5).

\section{Discussion}

Escherichia coli is one of the most common hosts for the production of recombinant proteins; however, the identification of high expressing clones, particularly at lab-scale, is labor-intensive and time-consuming and is often based on traditional methods, namely SDS-PAGE $[2,5]$. To date, several high-throughput platforms have been developed to screen the protein expression, most of which focus on automation using robots and qualitative/semi-quantitative screening. These high-throughput technologies allow researchers to screen a large number of clones and remarkably shorten the timeline of protein production at large scale [16]. There are several commercial robotic platforms, such as Equator GX8 Dispenser, MicroSys, and sciFLEXARRAYER dispenser for genomic and proteomic applications, including protein array, antibody array, peptide binding assay, cell-based assay, protein crystallization, and protein expression. These technologies can rapidly transform bacteria, pick colonies based on qualitative or semi-quantitative criteria, screen the protein expression, or even purify the expressed proteins in biological procedures with little human labor. Nonetheless, these platforms are too expensive for most laboratories and need efficient specialists for caring and maintenance of equipments, making them unaffordable in the practice. Hence, if a protein production process does not have a sufficient number of samples to prove this level of cost, it is better to apply a manual method in parallel [17]. However, these manual methods analyze the protein expression within several weeks at a high cost. To resolve such problems, in the current work, we developed a manual method screening a large number of clones just $6 \mathrm{~h}$ after the inoculation of newly transformed bacteria to the medium. The method benefits from the following advantages: (i) screening capability in special conditions, such as different temperatures, various media, and variant or fusion expression; (ii) less batch to batch variability; (iii) better handling due to micro-scale; (iv) less error-prone by reducing the steps; (v) screening without employing expensive equipment [2]; (vi) more cost-effective than other screening methods owing to the removal of inducer; (vii) selection in a short time due to the elimination of colony culturing step on LB agar plate, the removal of preculture/induction steps, and the SDSPAGE technique; (viii) simplicity; (ix) potential capability (a)

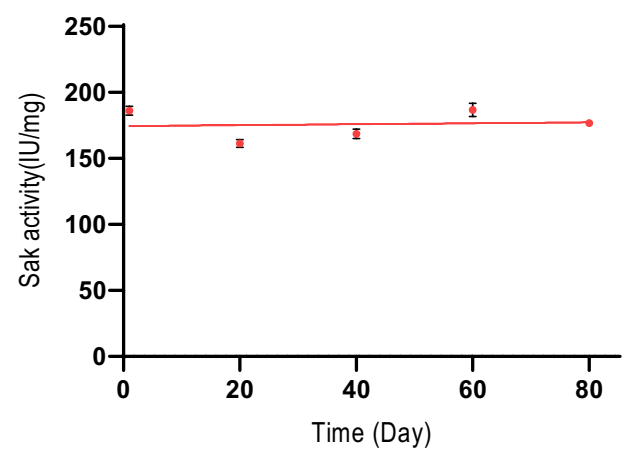

(b)

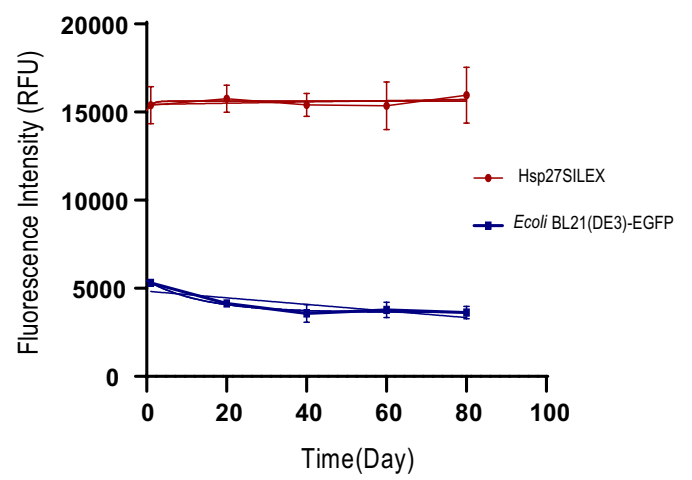

Fig. 3 The expression stability of dicistronic SILEX system within 80 days after four freeze-thaw cycles. a The SAK chromogenic activity and $\mathbf{b}$ fluorescent signals. The intensity of fluorescent signals in E. coli BL21 (DE3) transformed with pET28a-sak-rbs-egfp was measured as the negative control to evaluate the basal expression of eGFP. Data are represented as Mean \pm SD from three independent measurements 
for automation and use at large scale; $(\mathrm{x})$ obtaining stable high expressing clones due to Hsp27 co-expression; and most importantly, (xi) quantitative screening. Numerous attempts have been previously made to develop a simple and rapid screening method. For example, in a study, the protein expression was monitored by the fusion of photoactive yellow protein to the target protein and the protein concentration and purity were quantified employing a spectrometer within a few minutes [18]. The method, however, needs the addition of a precursor to develop the color that imposes more cost to the system. To this end, herein, we applied an eGFP that does not need any exogenous substrates or cofactors for detection. The attempts by Vincentelli illustrated that the level of soluble protein can be measured in one 96 well-microplate by SDS-PAGE or four 96 well-microplates by dot blot and SDS-PAGE per week. The number of cultures can also be increased up to $1152(12 \times 96$ well-microplates $)$ in parallel over 1 week if the process is performed by semiautomated methods, such as liquid handling robots, dot blot, and high-throughput electrophoresis [2]. While in our facilitated protocol, the newly transformed bacteria can be directly inoculated to the medium and screened by fluorescent signals in 96-well microplates. In another study, the intensity of fluorescent signals was measured to analyze the soluble and insoluble proteins. This approach has the following steps: (1) plating different dilutions of transformants on agar plates; (2) cultivation of single colonies in 96-deep-well microplates; (3) induction of expression by adding IPTG; (4) measuring the fluorescent signals by a fluorimeter; (5) and finally, analyzing the soluble and insoluble fractions with SDSPAGE and western blot [19]. In our previous study, we stated that autoinduction by Hsp27 is a convenient way to produce recombinant proteins without IPTG addition [20]. The developed autoinducible system does not need optical density monitoring, therefore reducing the operator intervention, which is preferable for high-throughput purposes. Additionally, autoinducible systems decrease the cost of production and host cytotoxicity by eliminating the inducer. It is also recommended that the screening protocols must be established at small scales (1-4 ml) to achieve high-throughput capability $[2,16]$. In this regard, the current robotic platforms reduce the culture volume by replacing shaker flasks with microplates [21, 22]. Similarly, our screening protocol was optimized at microscale [4]. The correlation analysis of fluorescent signals and enzyme activity revealed that there is a positive relationship between the expression of eGFP and model protein. This is in agreement with previous studies because the transcription of genes was regulated by one promoter in dicistronic vectors $[10,12]$.
Surprisingly, the designed system resulted in obtaining stable colonies as the high expressing clones kept the initial expression level even after several cycles of freeze-thaw for 80 days. Moreover, our data confirmed the plasmid stability of clones for 500 days. These stabilities can be attributed to the presence of Hsp27 increasing naturally under stress conditions, such as hypoxia, extreme $\mathrm{pH}$ or temperatures, and the presence of antibiotics or toxins. The simultaneous expression of heat shock protein with the target protein can rapidly prevent instability and decrease the stress induced by repeated freeze-thaw cycles [23]. This phenomenon is also in agreement with our previous study on SILEX systems [20]. Moreover, since heat shock proteins also act as chaperones, the use of bacteria- or human-originated heat shock proteins in these systems can offer better folding of the complex proteins that need further investigations [24-28].

\section{Conclusion}

As shown in the present work, the combination of dicistronic and autoinducible systems could be employed for developing a rapid and facilitated procedure to screen high-expressing $E$. coli colonies. The developed protocol can be applied as a simple screening method in laboratories without any special equipment owing to the removal of preculture step to save time and cost for the detection of expression. There is also no need for adding an external inducer and elimination of induction step. Simultaneous screening of a large number of clones in a short time, good expression stability after several freeze-thawing cycles, a high correlation between the expression of two genes, and most importantly, quantitative measurement of protein expression at different clones were also among the important advantages of this system. Moreover, the recommended protocol is fully compatible with automation platforms for industrial purposes.

\section{Materials and methods}

\section{E. coli strains, plasmids, and growth conditions}

Top10 and DH5-a E. coli strains were applied for plasmid propagation and BL21 (DE3) was used for the expression of SAK and eGFP. All the strains were received from the national cell bank of Iran (Pasteur Institute of Iran). The double-transformed bacteria were grown aerobically in Luria Bertani (LB) broth or agar plate supplemented with the appropriate antibiotics $(35 \mu \mathrm{g} / \mathrm{ml}$ kanamycin and $100 \mu \mathrm{g} / \mathrm{ml}$ ampicillin) at $37^{\circ} \mathrm{C}$. 


\section{Design of dicistronic SILEX system}

The nucleotide sequences encoding Hsp27 (P04792), staphylokinase (sak, p68802), and an eGFP protein (peGFP plasmid, Addgene, USA) were optimized and synthesized by Biomatik Canadian Company. The expression cassette containing sak and egfp was cloned into pET28a within XbaI and XhoI restriction sites. The $h s p 27$ gene was cloned into pET21a vector within NdeI and XhoI restriction sites. The schematic representations of constructs and the system are depicted in (Additional file 9: Fig. S6).

\section{Design of screening protocol}

\section{Optimization of facilitated protocol for colony screening}

The following steps were considered in the optimization of facilitated screening protocol through a dicistronic expression system containing eGFP and SAK protein autoinduced by a system comprising Hsp27 as an autoinducer: (1) optimization of double transformation protocol in terms of optical density of bacterial culture $\left(\mathrm{OD}_{600 \mathrm{~nm}}\right.$ of $0.3,0.4,0.45$, and 0.5$)$ for entering to the competent stage, the use of different plasmid amounts $(200,300,400$, and $500 \mathrm{ng})$ to obtain a specific number of transformants ( 100 transformants) for transferring a clone in each well of 96-microplate; (2) optimization of incubation time in cold $\mathrm{CaCl}_{2}$ solution (15 min to $18 \mathrm{~h}$ ) for competent cell preparation for obtaining $\sim 100$ double-transformed bacteria; (3) investigation of different volumes of transformation solution $(2,10,12,20$, and $25 \mu \mathrm{l}$ ) for obtaining a single double-transformed colony in each well of 96-well microplates and removing the overnight culture step for protein expression; and (4) determination of optimal time to record fluorescence signals on account of eGFP expression (minimum time required for more accurate screening of protein expression). In this test, fluorescent signals were measured for 10 different clones of dicistronic SILEX system within $6 \mathrm{~h}$ with an interval of $1 \mathrm{~h}$. Moreover, the fluorescence sensitivity of the device was adjusted to the specified values (60, 70, and $80 \mathrm{RFU}$ ) and eGFP expression signal was measured for 26 individual clones $6 \mathrm{~h}$ after inoculation. Because if the sensitivity of the fluorimeter is more than a threshold, eGFP expression is out of the detection range (overflow) and if is less than a threshold, it interferes with the background signals. Moreover, the precision, linearity, the limit of detection (LOD), and the limit of quantification (LOQ) were measured for the facilitated protocol. The precision was determined by measuring relative standard deviation (RSD). The detection and quantification limits were determined for 10 samples as a mean of sample blank value plus three and 10 times of its standard deviation, respectively. The LOD can be expressed as the smallest amount or concentration of eGFP that can be reliably detected or distinguished from the background signal of fluorimeter device and blank sample (the suspension of $E$. coli culture without pET28a -sak rbs egfp plasmid). The limit of quantifying a specific analytical procedure can be determined as the smallest amount or concentration of eGFP that can be measured quantitatively with acceptable precision and accuracy [15].

\section{Expression analysis of SAK with SDS-PAGE, western blot, and purification}

The expression of SAK protein was analyzed by use of SDS-PAGE, western blot, and affinity purification. Briefly, a clone was inoculated into a 5-ml LB medium containing $100 \mu \mathrm{g} / \mathrm{ml}$ of ampicillin and $35 \mathrm{of} \mu \mathrm{g} / \mathrm{ml} \mathrm{kan-}$ amycin and incubated for $16 \mathrm{~h}$ in a shaker incubator at $37{ }^{\circ} \mathrm{C} / 170 \mathrm{rpm}$. Afterwards, the $5-\mathrm{ml}$ and $1-\mathrm{L} \mathrm{LB}$ cultures were respectively inoculated by $100 \mu \mathrm{l}$ and $20 \mathrm{ml}$ pre-culture and incubated at $37{ }^{\circ} \mathrm{C} / 250 \mathrm{rpm}$ overnight. The SAK expression was analyzed through the use of 15\% gel SDS-PAGE and Coomassie blue staining method and confirmed with western blot technique. In brief, the sample was transferred on nitrocellulose membrane (Sigma-Aldrich, USA) and blocked with a TBST buffer (Tris-buffered saline (Tris $20 \mathrm{mM}$ with $\mathrm{pH}: 7.5, \mathrm{NaCl}$ $150 \mathrm{mM}$ ), $0.1 \%$ Tween 20 , and $3 \%$ bovine serum albumin) for $2 \mathrm{~h}$. The membrane was then incubated in a buffer containing anti-HisTag antibody (Sigma- Aldrich, USA) with a dilution of $1: 2000$ at $4{ }^{\circ} \mathrm{C}$ for $16 \mathrm{~h}$. Finally, the protein band was visualized by adding DAB (3, 3'-Diaminobenzidine) and $\mathrm{H}_{2} \mathrm{O}_{2}$. To purify SAK, the pellet was resuspended in the lysis buffer $(300 \mathrm{mM} \mathrm{NaCl}, 50 \mathrm{mM}$ $\mathrm{NaH}_{2} \mathrm{PO}_{4} \cdot 2 \mathrm{H}_{2} \mathrm{O}, 1 \mathrm{mg} / \mathrm{ml}$ lysozyme, $\mathrm{pH} 8$ ) and lysed by sonication on ice for $20 \mathrm{~min}$. The lysate was then centrifuged at $14,000 \mathrm{~g}$ for $25 \mathrm{~min}$ at $4{ }^{\circ} \mathrm{C}$ and the supernatant was loaded on an equilibrated Ni-NTA resin (Qiagen, USA) for $1 \mathrm{~h}$ at $4{ }^{\circ} \mathrm{C}$ according to the manufacturer's protocol. The resin was washed three times with the wash buffer $\left(300 \mathrm{mM} \mathrm{NaCl}, 50 \mathrm{mM} \mathrm{NaH} \mathrm{PO}_{4} \cdot 2 \mathrm{H}_{2} \mathrm{O}, 20 \mathrm{mM}\right.$ imidazole, $\mathrm{pH}$ 8). Lastly, the protein was eluted by a buffer containing $300 \mathrm{mM} \mathrm{NaCl}, 50 \mathrm{mM} \mathrm{NaH}{ }_{2} \mathrm{PO}_{4} \cdot 2 \mathrm{H}_{2} \mathrm{O}$, and $250 \mathrm{mM}$ imidazole (adjusted to $\mathrm{pH} 8$ ).

\section{Enzyme activity measurement}

The SAK activity was determined qualitatively and quantitatively respectively applying radial caseinolytic assay and chromogenic methods. In the radial caseinolytic assay, a double-transformed clone was inoculated into a $5-\mathrm{ml} \mathrm{LB}$ medium supplemented with $35 \mu \mathrm{g} / \mathrm{ml}$ of kanamycin and $100 \mu \mathrm{g} / \mathrm{ml}$ of ampicillin and incubated in a shaker incubator at $37^{\circ} \mathrm{C} / 170 \mathrm{rpm}$ overnight. Afterwards, $100 \mu \mathrm{l}$ of the suspension was added to a 5 - $\mathrm{ml} \mathrm{LB}$ medium and incubated at $37^{\circ} \mathrm{C} / 250 \mathrm{rpm}$ for $16 \mathrm{~h}$. The culture was then centrifuged at $4{ }^{\circ} \mathrm{C} / 4000 \mathrm{~g}$ and the pellet was washed 
twice with cold PBS. The pellet was resuspended in the lysis buffer $\left(50 \mathrm{mM} \mathrm{NaH} \mathrm{PO}_{4} \cdot 2 \mathrm{H}_{2} \mathrm{O}, 300 \mathrm{mM} \mathrm{NaCl}\right.$, $1 \mathrm{mg} / \mathrm{ml}$ lysozyme, $\mathrm{pH}$ 7.5). The lysate was then poured into the holes on $5 \%$ skim milk agar plates $(0.05 \mathrm{~g} / \mathrm{ml}$ skim milk, $0.04 \mathrm{~g} / \mathrm{ml} \mathrm{LB}$ agar, $50 \mathrm{mM}$ Tris- $\mathrm{HCl}, 0.15 \mathrm{M}$ $\mathrm{NaCl}, \mathrm{pH} 7.5)$ supplemented with $8 \mu \mathrm{l}$ of Glu-plasminogen $(142.85 \mu \mathrm{M})$ in triplicate and incubated at $37^{\circ} \mathrm{C}$ for $18 \mathrm{~h}$. The reference SAK (Prospect, 50,000 IU/mg) with and without Glu-plasminogen were utilized as positive and negative controls, respectively [29]. The clear zone diameters were then determined by ImageJ software (https://imagej.nih.gov/ij/index.html).

In the chromogenic method, nine precultures of the double transformed colonies were separately inoculated into a 5-ml LB medium and incubated for $16 \mathrm{~h}$ at $37^{\circ} \mathrm{C} / 170 \mathrm{rpm}$. Afterwards, $10 \mu \mathrm{l}$ of bacterial suspensions $\left(\mathrm{OD}_{600 \mathrm{~nm}}=\sim 2.5\right)$ were added into a well of 96-microplate containing $190 \mu \mathrm{l}$ of LB broth supplemented with $35 \mu \mathrm{g} /$ $\mathrm{ml}$ of kanamycin and $100 \mu \mathrm{g} / \mathrm{ml}$ of ampicillin in triplicate. The plate was incubated at $37^{\circ} \mathrm{C} / 90 \mathrm{rpm}$ for $6 \mathrm{~h}$. Finally, the activity of SAK in the clones was determined according to an activity-absorbance standard curve. To obtain the standard curve, serial dilutions of the reference SAK was prepared and 8 of $\mu$ human Glu-plasminogen solution $(142.85 \mu \mathrm{M}$, Invitrogen) was mixed with $30 \mu \mathrm{l}$ of SAK standard solutions $(0.04,0.09,0.39,0.75,1.56,6.25$, and $13.5 \mu \mathrm{M}$, Prospect) in triplicates and the plate was incubated for $25 \mathrm{~min}$ at $37{ }^{\circ} \mathrm{C}$ [30]. Afterwards, $7 \mu \mathrm{l}$ of H-D-Val-Leu-Lys-paranitroanilide as plasminogen substrate $(50 \mathrm{mg} / \mathrm{ml}, \mathrm{S} 2251$, Sigma-Aldrich) was added to the wells and the plate was incubated for $30 \mathrm{~min}$ at $37^{\circ} \mathrm{C}$. Finally, the absorbance was measured at a wavelength of $405 \mathrm{~nm}$.

\section{Correlation study between fluorescence signals and SAK activity}

To investigate the association between fluorescence signals and SAK activity, 50 precultures of double-transformed colonies were separately inoculated into a $5-\mathrm{ml}$ LB medium and incubated for $16 \mathrm{~h}$ at $37{ }^{\circ} \mathrm{C} / 170 \mathrm{rpm}$. Next, $10 \mu \mathrm{l}$ of bacterial suspensions $\left(\mathrm{OD}_{600 \mathrm{~nm}}=\sim 2.5\right)$ were added to a 96-microplate containing $190 \mu \mathrm{l}$ of LB broth supplemented with $35 \mu \mathrm{g} / \mathrm{ml}$ of kanamycin and $100 \mu \mathrm{g} / \mathrm{ml}$ of ampicillin in triplicate. The plate was incubated at $37{ }^{\circ} \mathrm{C} / 90 \mathrm{rpm}$ for $6 \mathrm{~h}$. The fluorescent signals were finally measured using a fluorimeter $(485 \mathrm{~nm}$ excitation and $528 \mathrm{~nm}$ emission, BioTek, USA). Then, 10 clones with high and low fluorescence signals (five clones for each group) were selected, inoculated individually into a $5 \mathrm{ml} \mathrm{LB}$ medium, and incubated for $16 \mathrm{~h}$ at $37{ }^{\circ} \mathrm{C} / 170 \mathrm{rpm}$. Subsequently, $10 \mu \mathrm{l}$ of bacterial precultures was transferred into a 96 wells-microplate containing $190 \mu \mathrm{l}$ of LB broth and the selective antibiotics in triplicate and the plate was incubated for $6 \mathrm{~h}$ at $37^{\circ} \mathrm{C} / 90 \mathrm{rpm}$. The fluorescent signals were finally measured using fluorimetry $(485 \mathrm{~nm}$ excitation and $528 \mathrm{~nm}$ emission, BioTek, USA). For enzyme activity measurement, $8 \mu \mathrm{l}$ of Glu-plasminogen $(142.85 \mu \mathrm{M})$ was added to $200 \mu \mathrm{l}$ of bacterial suspensions and the mixtures were incubated for $30 \mathrm{~min}$ at $25{ }^{\circ} \mathrm{C}$ in triplicate. Following incubation, $7 \mu \mathrm{l}$ of synthetic substrate $\mathrm{S} 2251(50 \mathrm{mg} /$ $\mathrm{ml}$ ) was added to the mixtures and the absorbance was measured at a wavelength of $405 \mathrm{~nm}$ with a spectrophotometer (Epoch, BioTek, USA).

\section{Expression and plasmid stability of dicistronic system}

The expression stability was measured after four freezethawing cycles at $-70{ }^{\circ} \mathrm{C}$ for three clones. In brief, the bacteria were double-transformed with the plasmids and the fluorescent intensity and the enzyme activity were measured as mentioned before. The double-transformed bacteria were stored at $-70{ }^{\circ} \mathrm{C}$ and after 20 days, $100 \mu \mathrm{l}$ of glycerol stocks were inoculated into a 5-ml LB broth medium supplemented with the selective antibiotics and incubated for $16 \mathrm{~h}$ at $37{ }^{\circ} \mathrm{C} / 170 \mathrm{rpm}$. Afterwards, $100 \mu \mathrm{l}$ of precultures were inoculated to a $5-\mathrm{ml} \mathrm{LB}$ broth and incubated for $16 \mathrm{~h}$ at $37{ }^{\circ} \mathrm{C} / 250 \mathrm{rpm}$ and the fluorescent intensity and the enzyme activity of clones were measured again. The freeze-thawing cycle was repeated four times within 80 days. The plasmid stability was also investigated with colony PCR after 500 days of subculturing on LB agar plates with 10 days intervals. Universal T7-promoter and T7-terminator primers were utilized to amplify the genes ( $h s p 27$ and $s a k r b s$ egfp). Briefly, the pellet obtained from a newly cultured clone was lysed by boiling and added to a PCR reaction containing $2 \mu \mathrm{l}$ of forward and reverse primers $(20 \mu \mathrm{M}), 10 \mu \mathrm{l}$ of Taq DNA Polymerase Master Mix-Amicon, and $\mathrm{ddH}_{2} \mathrm{O}$ up to $50 \mu \mathrm{l}$. The PCR program was as follows: $95{ }^{\circ} \mathrm{C}$ for $5 \mathrm{~min}$ (one cycle); $95^{\circ} \mathrm{C}$ for $30 \mathrm{~s} ; 49^{\circ} \mathrm{C}$ for $30 \mathrm{~s}$; and $72{ }^{\circ} \mathrm{C}$ for $30 \mathrm{~s}$ (35 cycles); and a final extension of $72^{\circ} \mathrm{C}$ for $10 \mathrm{~min}$.

\section{The screening protocol}

The developed screening protocol is as follows. The schematic representation of the screening protocol is also portrayed in Fig. 4.

1. Inoculate $200 \mu \mathrm{l}$ of seed culture into a $5-\mathrm{ml} \mathrm{LB}$ broth;

2. Incubate the culture at $37{ }^{\circ} \mathrm{C} / 250 \mathrm{rpm}$ up to $\mathrm{OD}_{600 \mathrm{~nm}} \sim 0.5$

3. Centrifuge the culture at $4{ }^{\circ} \mathrm{C} / 4000 g$ for $5 \mathrm{~min}$ and resuspend the pellet in $1200 \mu \mathrm{l}$ cold $\mathrm{CaCl}_{2}(0.1 \mathrm{M})$;

4. Incubate the bacterial suspension at $4{ }^{\circ} \mathrm{C}$ for $15 \mathrm{~min}$; 

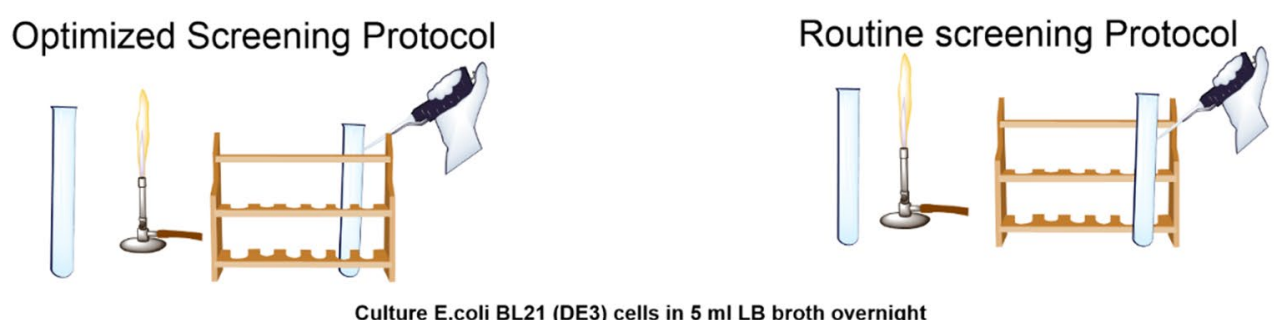

Culture E.coli BL21 (DE3) cells in $5 \mathrm{mI}$ LB broth overnight

\section{Competention \& Transformation}
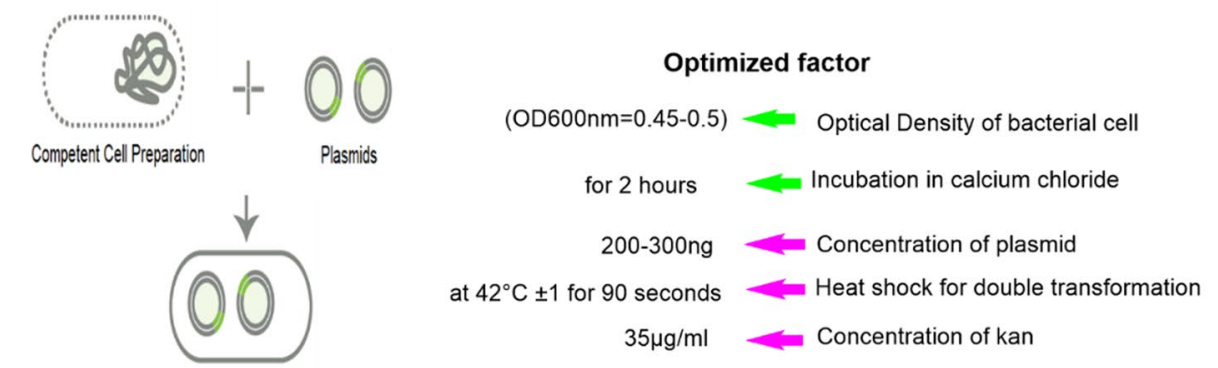

Double Transformation

Transformation mix

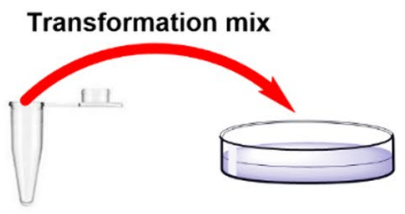

Incubation at $37^{\circ} \mathrm{C}$ overnight<smiles>C1CCCCC1</smiles>

Colony picking and prepration preculture

Measuring of flourescent signals and screening high expressing clones
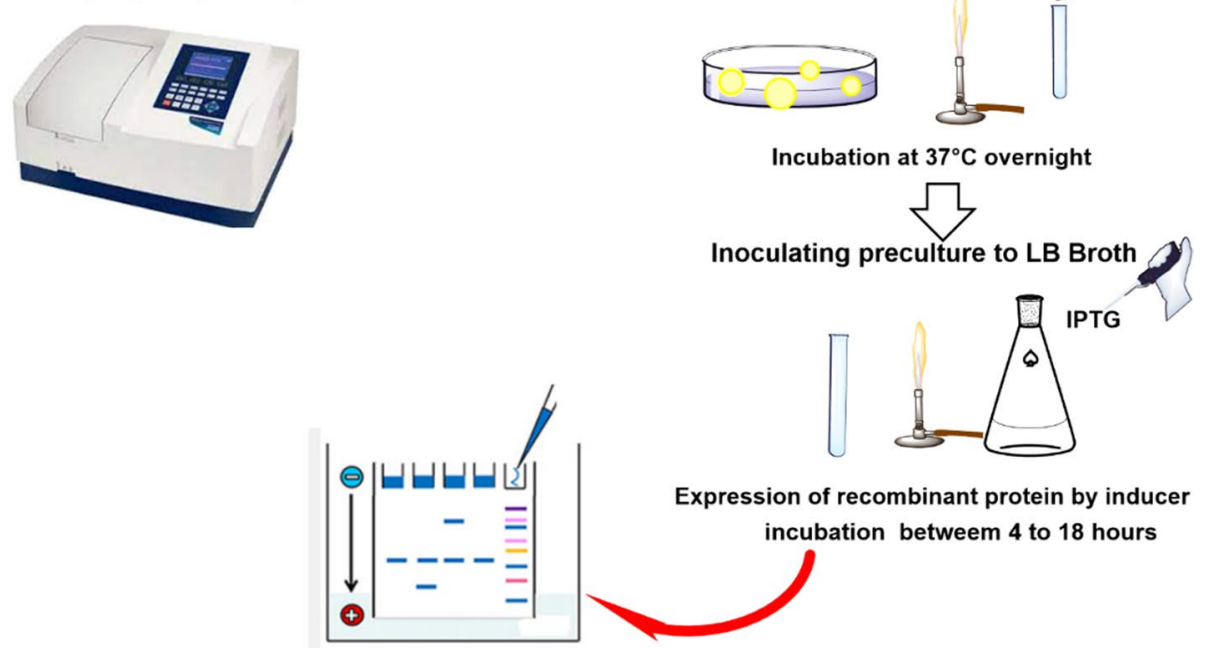

Monitoring of expression by SDS-PAGE

Fig. 4 The schematic representation of the developed screening protocol 
5. Centrifuge the bacterial suspension at $4{ }^{\circ} \mathrm{C} / 4000 g$ for $5 \mathrm{~min}$;

6. Add $1200 \mu \mathrm{l}$ of cold $\mathrm{CaCl}_{2}(0.1 \mathrm{M})$ to the pellet, resuspend it, and incubate the bacterial suspension at $4{ }^{\circ} \mathrm{C}$ for $2 \mathrm{~h}$;

7. Centrifuge the bacterial suspension at $4{ }^{\circ} \mathrm{C} / 4000 \mathrm{~g}$ for 5 min;

8. Resuspend the pellet in $300 \mu \mathrm{l}$ of cold $\mathrm{CaCl}_{2}(0.1 \mathrm{M})$ to obtain the competent cells;

9. Add pET21a-hsp27 and pET28a-sak-rbs-egfp plasmids (200-300 ng) to $100 \mu \mathrm{l}$ of the competent cells;

10. Incubate the mixture at $4{ }^{\circ} \mathrm{C}$ for $30 \mathrm{~min}$ and then for $90 \mathrm{~s}$ at $42^{\circ} \mathrm{C}$;

11. Transfer the mixture on ice for 3 min immediately;

12. Add $1 \mathrm{ml}$ of LB broth to the double-transformed bacteria and incubate for $1 \mathrm{~h}$ at $37^{\circ} \mathrm{C} / 220 \mathrm{rpm}$;

13. Inoculate $10 \mu \mathrm{l}$ of the transformed cells into the wells of a 96-microplate containing $190 \mu \mathrm{l}$ of LB broth supplemented with selective antibiotics (herein, $35 \mu \mathrm{g} / \mathrm{ml}$ kanamycin and $100 \mu \mathrm{g} / \mathrm{ml}$ ampicillin);

14. Incubate the microplate at $37^{\circ} \mathrm{C} / 90 \mathrm{rpm}$ for $6 \mathrm{~h}$;

15. Screen high expressing colonies using fluorimetry (485 $\mathrm{nm}$ excitation and $528 \mathrm{~nm}$ emission).

\section{Statistical analysis and additional materials and methods}

All data were statistically analyzed with SPSS software version 25. Plotting and curve fitting was performed using Prism software version 8. Materials and methods for supplementary files were provided in Additional file 10.

\section{Abbreviations}

eGFP: Enhanced green fluorescent protein; SAK: Staphylokinase; LOD: Limit of detection; LOQ: Limit of quantification; FACS: Fluorescence-activated cell sorting; RBS: Ribosome-binding sites; SILEX: Self-induced expression system; RFU: Relative fluorescent unit; RSD: Relative standard deviation; TBST:Tris-buffered saline.

\section{Supplementary Information}

The online version contains supplementary material available at https://doi. org/10.1186/s12934-021-01711-2.

\footnotetext{
Additional file 1: Table S1. Optimization of plasmid amount and $\mathrm{OD}_{600 \mathrm{~nm}}$ of bacterial cultures at the double-transformation process to obtain approximately 100 colones.

Additional file 2: Table S2. Optimization of transferring different volumes of transformation suspension to obtain a single clone in each well of 96-well microplates. Data are represented from three independent experiments

Additional file 3: Fig. S1. Time determination for fluorimetry.

Additional file 4: Fig. S2. Fluorescence sensitivity measurements. Fluorescent signals were measured for 26 clones at the sensitivities of 60,70 , and 80 . The only signals with a relative fluorescence unit (RFU) of
}

$<100,000$ were pointed out in the figure because the others were out of detection (overflow). The sensitivity of 60 was chosen because the fluorescent signals for all the clones were measurable while five and 11 clones were out of detection for the sensitivity of 70 and 80 , respectively.

Additional file 5: Fig. S3. SAK activity measurement on 5\% skim milkagar plate in presence of plasminogen: (i) wells 1, 2, and 3, reference SAK without adding plasminogen (as a negative control, triplicate); (ii) wells 4, 5, and 6, reference SAK with adding plasminogen (as a positive control, triplicate); (iii) wells 7, 8, and 9, the expressed SAK in dicistronic SILEX system at three different clones.

Additional file 6: Fig. S4. The standard curve for the SAK activity. Data are represented as Mean \pm SD from three independent measurements. There is a linear relationship between the SAK activity $(\mathrm{IU} / \mathrm{mg})$ and the absorbance at a wavelength of $405 \mathrm{~nm}$.

Additional file 7: Table S3. Screening of 50 clones by fluorimetry $6 \mathrm{~h}$ after inoculation in a 96-well microplate. Ten clones with maximum and minimum fluorescent signals were selected for the enzyme activity assay.

Additional file 8: Fig. S5. The plasmid stability in dicistronic SILEX system after 500 days of subculturing. The PCR amplified bands were visualized on 2\% gel agarose. Lane1, E. coli BL21(DE3) without plasmids (negative control); Lane 2, DNA Ladder; Lane 3, a newly double-transformed E. coli BL21(DE3) containing pET21a-hsp70 (1927 bp for hsp70) and pET28a-sakrbs-egfp (1024 bp for egfp) as a positive control; Lane 4, dicistronic SILEX system containing pET21a-hsp27 (619 bp for hsp27) and pET28a-sak-rbsegfp (1024 bp for egfp) after 500 days of subculturing.

Additional file 9: Fig. S6. The schematic representation of (a) the designed constructs and (b) dicistronic SILEX system.

Additional file 10. Additional materials and methods for additional files 1 to 9.

\section{Acknowledgements}

The project was financially supported by Pasteur Institute of Iran. The authors wish to express their deep gratitude to all who provided support during the course.

\section{Authors' contributions}

RAC and MK designed the study. FSS conducted the experiments and drafted the manuscript. RAC, MK, DN, and W analyzed and interpreted the results. All authors read and approved the final manuscript.

Funding

This work was supported by Pasteur Institute of Iran.

Availability of data and materials

All data generated or analyzed during this study are included in the published article and supplementary file and or are available from the corresponding author on reasonable request.

\section{Declarations}

Ethics approval and consent to participate Not applicable.

\section{Consent for publication}

Not applicable.

\section{Competing interests}

The authors declare that they have no competing interests.

Received: 29 June 2021 Accepted: 23 November 2021

Published online: 11 December 2021 


\section{References}

1. Schreiber C, Müller H, Birrenbach O, Klein M, Heerd D, Weidner T, Salzig D, Czermak P. A high-throughput expression screening platform to optimize the production of antimicrobial peptides. Microb Cell Fact. 2017;16:1-13.

2. Vincentelli R, Cimino A, Geerlof A, Kubo A, Satou Y, Cambillau C. Highthroughput protein expression screening and purification in Escherichia coli. Methods. 2011:55:65-72.

3. Herzenberg LA, Sweet RG, Herzenberg LA. Fluorescence-activated cell sorting. Sci Am. 1976:234:108-18.

4. Stephens S, Figg A, Mann C, Atkinson R, Woodrough R. Automation for high-throughput identification and picking of GFP expressing colonies. J Assoc Lab Autom. 2002;7:41-3.

5. Eichmann J, Oberpaul M, Weidner T, Gerlach D, Czermak P. Selection of high producers from combinatorial libraries for the production of recombinant proteins in Escherichia coli and Vibrio natriegens. Front Bioeng Biotechnol. 2019:7:254.

6. Freimark D, Jérôme V, Freitag R. A GFP-based method facilitates clonal selection of transfected $\mathrm{CHO}$ cells. Weinheim: Wiley; 2010.

7. Jia B, Jeon CO. High-throughput recombinant protein expression in Escherichia coli: current status and future perspectives. Open Biol. 2016;6:160196.

8. Nommay A, Wilms B: Method of screening cell clones. Google Patents; 2016.

9. Salunkhe S, Varshney B, Soorapaneni S: Dual Cistronic Bacterial Expression System. Google Patents; 2019.

10. Kim KJ, Kim HE, Lee KH, Han W, Yi MJ, Jeong J, Oh BH. Two-promoter vector is highly efficient for overproduction of protein complexes. Protein Sci. 2004;13:1698-703.

11. Rucker P, Torti FM, Torti SV. Recombinant ferritin: modulation of subunit stoichiometry in bacterial expression systems. Protein Eng. 1997:10:967-73.

12. Sekhavati MH, Tahmoorespur M: Dual Promoter Vector Construction for Simultaneous Gene Expression Using SOE-PCR Technique. Iran J Appl Anim Sci. 2015.

13. Briand L, Marcion G, Kriznik A, Heydel J-M, Artur Y, Garrido C, Seigneuric R, Neiers F. A self-inducible heterologous protein expression system in Escherichia coli. Sci Rep. 2016;6:1-11.

14. Busso D, Stierlé M, Thierry J-C, Moras D. A comparison of inoculation methods to simplify recombinant protein expression screening in Escherichia coli. Biotechniques. 2008:44:101-6.

15. NATA: General accreditation guidance-validation and verification of quantitative and qualitative test methods. 2018.

16. Long Q, Liu X, Yang Y, Li L, Harvey L, McNeil B, Bai Z. The development and application of high throughput cultivation technology in bioprocess development. J Biotechnol. 2014;192:323-38.

17. May M. Automated sample preparation. Science. 2016;351:300-2.

18. Kim Y, Ganesan P, Ihee H. High-throughput instant quantification of protein expression and purity based on photoactive yellow protein turn off/on label. Protein Sci. 2013:22:1109-17.

19. Saez NJ, Nozach H, Blemont M, Vincentelli R. High throughput quantitative expression screening and purification applied to recombinant disulfide-rich venom proteins produced in E. coli. J Vis Exp. 2014. https:// doi.org/10.3791/51464.

20. Shariati FS, Keramati M, Valizadeh V, Cohan RA, Norouzian D. Comparison of $E$. coli based self-inducible expression systems containing different human heat shock proteins. Sci Rep. 2021;11:4576.

21. Grunzel P, Pilarek M, Steinbrück D, Neubauer A, Brand E, Kumke MU, Neubauer P, Krause M. Mini-scale cultivation method enables expeditious plasmid production in Escherichia coli. Biotechnol J. 2014;9:128-36.

22. Rohe $P$, Venkanna $D$, Kleine B, Freudl $R$, Oldiges M. An automated workflow for enhancing microbial bioprocess optimization on a novel microbioreactor platform. Microb Cell Fact. 2012:11:1-14.

23. Oganesyan N, Ankoudinova I, Kim S-H, Kim R. Effect of osmotic stress and heat shock in recombinant protein overexpression and crystallization. Protein Expr Purif. 2007;52:280-5.

24. Guzhova IV, Lazarev VF, Kaznacheeva AV, Ippolitova MV, Muronetz VI, Kinev AV, Margulis BA. Novel mechanism of Hsp70 chaperone-mediated prevention of polyglutamine aggregates in a cellular model of huntington disease. Hum Mol Genet. 2011;20:3953-63.

25. Makhoba XH, Burger A, Coertzen D, Zininga T, Birkholtz L-M, Shonhai A. Use of a chimeric Hsp70 to enhance the quality of recombinant
Plasmodium falciparum s-adenosylmethionine decarboxylase protein produced in Escherichia coli. PloS ONE. 2016;11:e0152626.

26. Cox D, Whiten DR, Brown JW, Horrocks MH, San Gil R, Dobson CM, Klenerman D, van Oijen AM, Ecroyd $H$. The small heat shock protein Hsp27 binds a-synuclein fibrils, preventing elongation and cytotoxicity. J Biol Chem. 2018;293:4486-97.

27. Bakthisaran $\mathrm{R}$, Tangirala R, Rao CM. Small heat shock proteins: role in cellular functions and pathology. Biochimica et Biophysica Acta. 2015:1854:291-319.

28. Tanaka N, Nakao S, Wadai H, Ikeda S, Chatellier J, Kunugi S. The substrate binding domain of DnaK facilitates slow protein refolding. Proc Natl Acad Sci. 2002;99:15398-403.

29. Shagufta Naseer B, Ravi M, Subhashchandra MG. Screening of staphylokinase producing Staphylococcus aureus from clinical samples. Int J Res Biol Sci. 2014;4:46-8.

30. Christner RB, Boyle MD. Role of staphylokinase in the acquisition of plasmin (ogen)-dependent enzymatic activity by staphylococci. J Infect Dis. 1996:173:104-12.

\section{Publisher's Note}

Springer Nature remains neutral with regard to jurisdictional claims in published maps and institutional affiliations.
Ready to submit your research? Choose BMC and benefit from

- fast, convenient online submission

- thorough peer review by experienced researchers in your field

- rapid publication on acceptance

- support for research data, including large and complex data types

- gold Open Access which fosters wider collaboration and increased citations

- maximum visibility for your research: over 100M website views per year

At BMC, research is always in progress.

Learn more biomedcentral.com/submissions 